University of California, Hastings College of the Law UC Hastings Scholarship Repository

Faculty Scholarship

1987

\title{
Granite Rock and the States' Influence Over Federal Land Use
}

John D. Leshy

UC Hastings College of the Law, leshyj@uchastings.edu

Follow this and additional works at: http://repository.uchastings.edu/faculty_scholarship

Part of the Natural Resources Law Commons

\section{Recommended Citation}

John D. Leshy, Granite Rock and the States' Influence Over Federal Land Use, 18 Envtl. L. 99 (1987).

Available at: http://repository.uchastings.edu/faculty_scholarship/372

This Article is brought to you for free and open access by UC Hastings Scholarship Repository. It has been accepted for inclusion in Faculty Scholarship

by an authorized administrator of UC Hastings Scholarship Repository. For more information, please contact marcusc@uchastings.edu. 


\section{Faculty Publications \\ UC Hastings College of the Law Library}

Author: John D. Leshy

Source: Environmental Law

Citation: $\quad 18$ Envtl. L. 99 (1987).

Title: $\quad$ Granite Rock And The States' Influence Over Federal Land Use

Originally published in ENVIRONMENTAL LAW. This article is reprinted with permission from ENVIRONMENTAL LAW and Lewis \& Clark Law School. 


\section{GRANITE ROCK AND THE STATES' INFLUENCE OVER FEDERAL LAND USE}

By

JOHN D. LESHY*

This article explores the implications of the United States Supreme Court's recent decision in California Coastal Commission v. Granite Rock Company for state-federal relations in the regulation of private activities conducted on federal multiple use lands. The decision gives the states considerable opportunity to influence the uses of these federal lands (managed primarily by the Forest Service and the Bureau of Land Management), by recognizing that states have some measure of independent regulatory authority over private activities being conducted on these lands. The author suggests, however, that the states (and local governments) might better advance their interests by participating more aggressively in the federal land and resource planning process, using the independent regulatory power confirmed by Granite Rock as a lever to help persuade the federal agencies to pay more attention to state concerns in the planning process. Similarly, the federal agencies might more constructively serve the national interest by being more accommodating to state environmental regulatory interests in the planning process. In this way, somewhat paradoxically, the Supreme Court decision confirming independent state regulatory power might help forge closer cooperation between these different governments.

\section{INTRODUCTION}

The Supreme Court's decision in California Coastal Commission v. Granite Rock Company ${ }^{1}$ leaves unanswered many ques-

* Professor of Law, Arizona State University. J.D. 1969, Harvard Univ.; A.B. 1966, Harvard College. I appreciate helpful comments received on an earlier draft of this manuscript from Robert Uram, Chris Berka, Frank Gregg, Larry MacDonnell, and Linus Masouredis. An earlier, much shortened version of this paper was delivered as a speech in Denver in April 1987 to a forum sponsored by the Natural Resources Law Center of the University of Colorado School of Law, and another version was delivered as an address to the annual Conference of Western Attorneys General in Berkeley, California in August 1987.

1. - U.S. -, 107 S. Ct. 1419 (1987). For a detailed discussion of Granite Rock's facts and disposition in the lower courts, see Jordan, California Coastal Commission v. Granite Rock Company: The States' Voice in Federal Mining Pol- 
tions about the scope of state regulatory authority over activities being conducted on federal land. But it is a significant victory for advocates of state power, for it allows the states to apply their own regulatory permitting statutes independently of parallel federal regulations. Thus the states possess a significant bit of leverage, if they choose to exercise it, in the delicate interplay between state and federal policymaking for federal lands. This article will identify and suggest answers to some of the questions that remain in the wake of the decision, and will offer some suggestions about how both the states and the federal government might constructively go about responding to it. ${ }^{2}$

The question presented by Granite Rock is not a trivial one. As Chief Justice Rehnquist has observed in a closely related context, because the federal lands comprise a substantial, even dominant, portion of lands within the borders of many states, especially western ones, activities taking place on those lands often have profound influence on the economy and overall quality of life in these states. ${ }^{3}$ Narrowly put, the issue in Granite Rock was whether the state of California could apply a state regulatory scheme to the company's plans to mine aspirin-grade limestone in a highly scenic area of the Big Sur coast, in the Los Padres National Forest. But because the Supreme Court's decision was rooted in the generic land and resource planning mandate of the Forest Service (and, by implication, of the Bureau of Land Management as well), it has a potentially much broader application.

From the perspective of this participant in the litigation, ${ }^{4}$ the Supreme Court's opinions contained some notable features. For one thing, the five justices in the majority ${ }^{5}$ spanned the Court's ideological spectrum, suggesting that environmental protection and rejuvenated federalism are not, in this age, mutually inconsistent. If enlightenment comes also from the states, as Justice

icy Gets Louder But Not Much Clearer, 18 Envtr. L. 181 (1987) (in this issue).

2. It will not, however, deal with the Coastal Zone Management Act issue addressed by the Court. See $107 \mathrm{~S}$. Ct. 1429-31.

3. United States v. New Mexico, 438 U.S. 696, 699 (1978).

4. I wrote a brief amicus curiae supporting California's position, filed on behalf of nineteen states and the Western Governors' Association.

5. Justice O'Connor wrote the majority opinion, joined by Justices Rehnquist, Brennan, Marshall and Blackmun. Justices Powell and Scalia wrote separate dissents, joined by Justices Stevens and White, respectively. 
Brennan has reminded us, ${ }^{6}$ a majority of the Court has now given state regulators an opportunity to show their own brand of wisdom, at least about how the environmental impacts of developments on federal lands might be controlled.

Neither the majority nor the two dissenting opinions plumbed the rich depths of the six-score year history of the federal Mining Law, ${ }^{7}$ history that exudes state authority over Mining Law activities on federal land. ${ }^{8}$ Instead, they each chose to put the issue in a more contemporary context, of whether the state regulation here was better characterized as an environmental regulation or as land use planning. ${ }^{9}$ This reformulation of the issue allowed them to escape, for the moment at least, the legacy of that history. Yet all nine justices seemed to agree, implicitly, that if the federal land planning statutes do not preempt state law, it is not otherwise preempted-at least not in the context of the Mining Law that furnishes the setting for the Granite Rock decision.

Another noteworthy feature of the decision is the almost complete absence of citation to precedent in any of the opinions. This disregard is curious because a number of modern courts have confronted exactly the same issue-whether a state has independent power to mitigate the environmental impacts of federally-authorized mining on federal lands. These recent precedents are found in decisions of the courts of several states and in one decision of the Court of Appeals for the Ninth Circuit (Ventura County) that was summarily affirmed seven years ago by the Supreme Court. ${ }^{10}$ None of these was mentioned in any of the opin-

6. Brennan, State Constitutions and the Protection of Individual Rights, 90 HARv. L. REv. 489, 499 (1977).

7. 30 U.S.C. $\S \S 21-54$ (1982). See generally J. Leshy, The Mining Law: A Study in Perpetual Motion (1987) (hereinafter The Mining Law).

8. See The Mining Law, supra note 7, at 184-85, 212-20.

9. See 107 S. Ct. at 1427-29; 1433-34 (Powell, J., dissenting); 1438-42 (Scalia, J., dissenting).

10. See State ex rel. Andrus v. Click, 97 Idaho 791, 554 P.2d 969 (1976) (Click I); State ex rel. Evans v. Click, 102 Idaho 443, 631 P.2d 614 (1981) (Click II), cert. denied sub nom. Click v. Idaho, 457 U.S. 1116 (1982); State ex rel. Cox v. Hibbard, 31 Or. App. 269, 570 P.2d 1190 (1977); Mt. Emmons Mining Co. v. Town of Crested Butte, 690 P.2d 231 (Colo. 1984); Elliott v. Oregon Int'l Mining Co., 60 Or. App. 474, 654 P.2d 663 (1982); Brubaker v. Bd. of County Comm'rs of El Paso County, 652 P.2d 1050 (Colo. 1982); Ventura County v. Gulf Oil Corp., 601 F.2d 1080 (9th Cir. 1979), aff'd mem., 445 U.S. 947 (1980). See also Skaw v. United 
ions, save for a rather throwaway reference to the Ninth Circuit decision by dissenting Justice Scalia. ${ }^{11}$ Their omission is particularly peculiar because one would have thought the primary reason the Court took this case was to resolve the conflict between the state court decisions and the Ventura County case.

These remarks need not be taken in a critical vein; the cryptic nature of the decision might be justified as simply an instance of the Court taking seriously its oft-repeated (if oft-violated) principle of deciding no more than necessary to dispose of the case at hand. ${ }^{12}$ What was necessary here was only to say whether the Granite Rock Company had to apply to the state Coastal Commission for a permit before conducting mining operations in the national forest. Nevertheless, despite Justice O'Connor's admonition that the majority decision was, in answering that question in the affirmative, "narrow,"1s it will inevitably have broader implications, as state and federal agencies and the lower courts now take up the task of sorting through state-federal conflicts that are not on all fours with the facts of Granite Rock.

\section{State and Local Powers After Granite Rock}

The Supreme Court's decision plainly gives a state the power to enforce its environmental regulatory laws by requiring permits from private entities conducting activities on federal land within its jurisdiction. A threshold question here is whether the state can order mining to cease until the requisite permit is obtained. Justice O'Connor's opinion for the majority is silent on the subject, but the answer would almost have to be yes. Being able to enforce the permit requirement with an injunction, at least if the ordinary requirements of injunctive relief were met, seems a nearly necessary corollary of being able to require the permit in the first place.

This implicates the Ninth Circuit decision in Ventura County, ${ }^{14}$ which laid considerable emphasis on the idea that enforcement of the local permit requirement there would have

States, 740 F.2d 932, 940-41 (Fed. Cir. 1984).

11. $107 \mathrm{~S}$. Ct. at 1440.

12. See, e.g., California v. United States, 438 U.S. 645, 672-73 (1978).

13. $107 \mathrm{~S}$. Ct. at 1431.

14. See Ventura County, 601 F. 2d at 1086. 
halted the activity. This point did not escape dissenting Justice Powell in Granite Rock, for he decried, as the "most troubling feature" of the majority's decision, that "if the Coastal Commission can require Granite Rock to secure a permit before allowing mining operations to proceed, it necessarily can forbid Granite Rock from conducting these operations." 15

If the state can enforce its permit requirement by injunctive relief, its leverage over the mining operation is made more concrete, because the burden of going forward in the courts has been substantially lifted from the shoulders of the state. Instead, the miner who wants to argue that stringent state regulation has been preempted, but who also wants to proceed with mining while the issue is litigated, will now be obliged either to comply with the state requirements, or to seek a stay of their enforcement from the courts.

\section{A. Environmental Regulation versus Land Use Planning}

Another, more weighty question is what differentiates a state environmental regulation from land use planning, for Justice O'Connor's opinion assumed, without deciding, that while the former is protected, the latter is preempted-a matter taken up in the next section. Justice 0 'Connor appreciated the impossibility of drawing a bright line between the two, and it is not easy to improve upon her explanation:

Land use planning in essence chooses particular uses for the land; environmental regulation, at its core, does not mandate particular uses of the land but requires only that, however land is used, damage to the environment is kept within prescribed limits. ${ }^{16}$

The slipperiness of the distinction offers a substantial opportunity to state and local governments, especially those who are willing to review and, if necessary, recharacterize their regulatory processes to shade them toward environmental regulation. This is not to suggest that the courts will be fooled merely by labels. Most judges are familiar with preemption cases; many judges have served in legislatures and understand the political process well enough to penetrate fabrications. But these cases almost in-

15. $107 \mathrm{~S}$. Ct. at $1436-37$.

16. Id. at 1428. 
evitably involve a careful sifting of facts, statutes and regulations, and, as Granite Rock itself demonstrates, ${ }^{17}$ how a state chooses to paint its regulatory objective can make a substantial difference in the -outcome. But Justice O'Connor's definition of environmental regulation leaves somewhat open the hard case, where the state is not seeking to mandate particular uses of the land, but where its effort to mitigate environmental damage effectively controls, if not how the land will be used, at least how it may not be used. If, for example, the Coastal Commission were to require, as a condition of Granite Rock's permit, that the company backfill and reclaim its open pit after mining, the cost might be so prohibitive as to forestall any mining in the first place. Is that reclamation requirement better characterized as land use planning or environmental regulation? This is the gray area sketched out by Justice O'Connor, where "a state environmental regulation [is] so severe that a particular land use would become commercially impracticable."18

The requirement to reclaim the land may dictate to some extent how the land is used-at least it would, in my hypothetical, rule out large-scale open pit mining. But underground mining or more limited, reclaimable surface mining might still be allowed. In any event the state is not dictating choices across the broad spectrum of non-mining uses, such as recreation or timber production. Moreover, reclamation is a classic environmental mitigation measure; a straightforward technique to ensure that, in Justice O'Connor's words, "damage to the environment is kept within prescribed limits." reclamation requirement is environmental protection rather than land use control. Ultimately, Granite Rock challenges state and local governments to show that this is their core concern in regulating.

This discussion illustrates an important feature of the power non-federal governments possess over activities on federal lands; namely, that it is almost wholly negative. Under any view of existing law, states generally lack power to insist that federal lands be used in a certain way. Instead, they can only control how they are used if either the federal government, or a private actor with

17. Id.

18. Id.

19. Id. 
permission from the federal government, wishes to embark on some activity. A state cannot, for example, issue a mineral lease or a grazing permit, sell timber, or even create a wildlife preserve or wilderness area on federal lands. All these remain the responsibility of the federal government. In this sense, Justice O'Connor's characterization of land use planning as "choos[ing] particular uses for the land"20 is largely inapplicable to state and local governments. They lack that power of choice except to the extent they might be able to limit available options so sharply as to leave the federal agency with practically no choice among possible land uses. Thus the distinction Justice O'Connor draws favors an expansive concept of state regulatory power.

\section{B. Limits on State Regulatory Power}

But how far can a state go in denying or imposing conditions on its permit? By itself a state permit gives the state only some procedural and timing leverage over activities on federal land. For the permit requirement to have genuinely substantive influence over how federal lands are managed, the state must have authority both to condition the permit upon compliance with substantive state controls over the mining operation and, possibly, to deny a permit if there are no circumstances under which the operation can proceed in compliance with state law.

Here too the Granite Rock majority avoided definitive resolution of this issue because it was not necessary to do so in the context of a threshold challenge to the state's permit requirement. But Justice O'Connor did address the issue obliquely, in discussing whether the state regulation in question was better characterized as a land use or an environmental regulation. This permitted her, in turn, to mention a couple of different formulations of the appropriate inquiry to be followed in passing on a state permit condition: first, whether the state's environmental regulation was "reasonable," and second, whether it was "so severe that a particular land use [became] commercially impracticable."21

In evaluating these suggestions, it may be useful to separate two issues: first, how far the state can go in regulating before it is

20. Id.

21. Id. at $1428-29$. 
preempted by federal law; and second, how far the state can go in regulating before it unconstitutionally takes whatever property right the miner possesses. The state courts, addressing these issues in the context of the Mining Law, have generally lumped them together, following some version of what has been called the "regulatory/prohibitory distinction"-that states have the power to regulate mining operations on federal land, but not to prohibit them. ${ }^{22}$

These courts are probably correct in meshing the two. From the beginning, the Mining Law has contemplated a large role for state and local governments; at the same time it has offered private miners the possibility, if certain conditions are satisfied, of acquiring property rights in federal land.$^{23}$ Thus, generally speaking, the federal interest for preemption analysis would seem to be adequately protected so long as the state did not regulate to the point of taking whatever property right the miner may have under federal law.

While the "regulatory-prohibitory distinction" has a nice ring to it, its application raises some important questions. One is whether proscribing a state veto means only that the state may not expressly prohibit mining or whether, instead, it prevents the state from regulating so heavily that the mining operation is effectively, though not expressly, prohibited. If it is the former, then the test is not very useful, because it merely counsels a state to hide its prohibitory intent behind onerous conditions attached to the permit to mine. But if it is the latter, it founders on the shoals of the federal statute under which Granite Rock is operating here-the Mining Law of 1872. That law's test for the validity of a mining claim, by which miners perfect valid property rights against the landowner United States, is whether the mining claimant has made a "discovery" of a "valuable mineral deposit." ${ }^{24}$ Establishing a discovery, a multitude of reported decisions has made clear, turns substantially on whether a commercially viable mineral deposit has been found..$^{25}$ And that, as numerous decisions hold, is influenced by the costs of extracting the deposit, including the cost of complying with applicable regu-

22. See state cases cited supra note 10.

23. See The Mining Law, supra note 7, at 184-85, 212-20.

24. 30 U.S.C. $\$ \S 22-23$ (1982).

25. See The Mining Law, supra note 7, at 135-67. 
latory requirements. ${ }^{26}$

Almost any state (or federal, for that matter) regulation is bound to increase a miner's cost of operations. If the regulation is onerous enough, the deposit may be rendered uneconomic to mine. If so, the miner's legal "discovery," and her property right, vanish, presumably without compensation. This possibility has not seemed to trouble the Supreme Court in the past. It has made clear, for example, that California could levy a tax on Granite Rock's interest in its unpatented mining claims, which would surely detract from the commercial viability of the deposit. ${ }^{27}$

Moreover, to say that a state (or the federal government) may regulate only to the extent it does not effectively prohibit mining leads to an odd result. Because it would limit the extensiveness of the regulation depending upon the economic viability of the particular operation, it would tend to allow regulation only of clearly profitable mining operations, and not marginal ones. But the state's interest in mitigating environmental impacts is not likely to vary with the profit margins of mining claimants. Indeed, it may often be true that economically marginal mining operations are the most environmentally destructive.

Like "takings" questions in general, this issue is likely to escape definitive generic resolution. Indeed, the hazards of applying the "regulatory-prohibitory distinction" might have counseled the Granite Rock majority to avoid an explicit endorsement of it, even to the point of neglecting to cite, much less discuss, the state court decisions that have adopted it. In the end, the agencies and the courts will probably muddle through by assessing the "reasonableness" of the state's environmental regulation. Perhaps we will even see employed in this context the late twentieth century judiciary's favorite buzzword, a "balancing"28 of the strength of the state's interest in mitigating environmental impacts against the legitimacy of the miner's expectation of a right to mine, leavened by whatever national interest one might find in the matter.

26. Id. at 162-63, 208-09.

27. Forbes v. Gracey, 94 U.S. 762, 765-66 (1877); see also Elder v. Wood, 208 U.S. 226, 232 (1908).

28. See, e.g., Aleinikoff, Constitutional Law in the Age of Balancing, 96 YALE L.J. 943 (1987). 
But if the courts ultimately mush up the issue by throwing around concepts like "reasonableness," the net effect will be to give the states substantial leverage over mining operations on federal lands. The courts will remain open to operators who think the states have gone too far, so it is important that states not regard their authority as plenary. But Granite Rock confirms the states' power to take that essential first step-to apply, independent of federal regulation, their own state permit processes, which carry with them some right to control how the activity will be conducted. And, when Granite Rock is considered in tandem with the Court's recent decision in Williamson County Regional Planning Commission v. Hamilton Bank, ${ }^{29}$ it seems to allow state and local authorities full opportunity to pass on objections to their exercise of regulatory power, in their own administrative processes, before issues of federal law growing out of that regulation are ripe for federal court review. That deference to state process might itself enhance state leverage.

Justice Scalia contends in his dissent that "any competent lawyer" faced with a state's demand that her client obtain a state permit to conduct activities on federal land would respond by saying that, once the federal government has approved the client's activity, it "does not require state approval."so This is a truly remarkable assertion, given the rich history of pervasive state and local regulation of all sorts of activities on federal land, ranging from hunting and fishing through air and water pollution to construction of buildings and disposal of waste. ${ }^{31}$ Moreover, as a practical matter, most often the easiest (and cheapest) response to a potential jurisdictional dispute is to apply for the permit and consider litigating preemption issues only if the permit conditions are deemed unacceptable. It is at least partly for this reason that many segments of the mining industry have for quite a few years not generally contested the exercise of state and local regulatory authority over their operations on federal land. ${ }^{32}$ Seen in this

29. 473 U.S. 172 (1985).

30. 107 S. Ct. at 1442 .

31. See, e.g., G. Coggins and C. Wilkinson, Federal Public Land and ReSOURCES LAW 209-37 (2d ed. 1987).

32. See, e.g., Friends of the Earth v. Butz, 406 F.Supp. 742, 747 (D.Mont. 1975), appeal dismissed as moot, 576 F.2d 1377 (9th Cir. 1978); Watson and Danielson, Environmental Mediation, 15 Nat. Resources Law. 687, 692, n.11 (1983); Kimball, Impact of BLM Surface Management Regulations on Exploration and 
light, Scalia's view would, in contrast to the majority opinion, have rather drastically altered the status quo.

\section{Do the Modern Federal Land Use Planning Statutes}

Preempt Independent Application of State Land Use (As

Opposed to Environmental) Regulations?

This is another question left unresolved in Granite Rock, because the majority characterized the Coastal Commission's regulations as "environmental" rather than "land use." Yet it did broach the topic, and assumed without deciding the issue that the modern federal land planning laws have preempted "the extension of state land use plans onto unpatented mining claims in national forest lands." "3s Future courts may have to consider the question, however, if they are faced with state regulations that they choose not to characterize as "environmental" in their orientation.

There is considerable room to challenge the assumption the Court made. The federal land planning statutes do, as the Court points out, call more for consultation and cooperation between state and federal governments than for independent application of state zoning plans. For example, the Federal Land Policy and Management Act of 1976 (FLPMA), ${ }^{34}$ the most full-blown version of modern congressional balancing of state and federal interests in land use planning for the federal lands, stops short of giving non-federal governments a land use planning-based veto over activities on federal lands managed by the Bureau of Land Management (BLM). Instead, the Secretary of the Interior is obliged to make federal land use plans "consistent with State and local

Mining Operations, 28 Rocky MTN. Min. L. INST. 509, 562-65 (1983). In Brubaker v. Bd. of County Comm'rs of El Paso County, 652 P.2d 1050 (Colo. 1982), for example, the federal mining claimants applied to the County Board of Supervisors for a special use permit for the proposed drilling on their federal claims, even though the decision in Ventura County v. Gulf Oil Corp., 601 F.2d 1080 (9th Cir. 1979), aff'd mem., 445 U.S. 947 (1980), counseled that local jurisdictions may not enforce a permit requirement. Similarly, Gulf itself later applied to the responsible Wyoming state agency for a permit to drill on its federal lease, even though

Ventura, which also involved a federal lease, seemed directly on point. See Gulf Oil Corp. v. Wyoming Oil and Gas Conservation Comm'n, 693 P.2d 227 (Wyo. 1985).

33. 107 S. Ct. at 1427.

34. 43 U.S.C.A. $\S \S 1701-84$ (West 1986 \& Supp. 1987). 
plans to the maximum extent he finds consistent with Federal law and the purposes of this Act." ${ }^{\text {ss }}$ Dissenting Justice Scalia found this language controlling, arguing that it would be "superfluous ... if the States were meant to have independent land use authority over federal lands." 36

But this provision does not necessarily oust the states from an independent role, for its phrasing sustains the interpretation that Congress merely wanted the Secretary of the Interior to make the initial judgment about whether state and local plans are preempted. These nonfederal governments still retain the right to seek judicial review of a secretarial decision preempting the applicability of their plans, to test whether preemption is "consistent with Federal law and the purposes of this Act." Under this view, Congress did not establish an automatic preemption of state and local land use planning authority in FLPMA. Rather, it left the matter up to the more traditional case-by-case review, by the agency initially, and then by the courts.

Other parts of FLPMA seem to confirm this view. The statute contains a disclaimer against repeals by implication, and also cautions that nothing in it "shall be construed . . . as a limitation upon . . . the police power of the respective States, or as . . . depriving any State or political subdivision thereof of any right it may have to exercise civil and criminal jurisdiction on [BLM] lands." 37

On the other hand, there remains the Ninth Circuit's 1979 decision in Ventura County, ${ }^{38}$ summarily affirmed by the Supreme Court. That decision can be interpreted as preventing the application of state land use planning requirements to operators on federal land - there, a county open space zoning permit scheme sought to be applied to a federal mineral lessee in a national forest. But the exact basis of the Ninth Circuit's decision is open to debate. The court emphasized, among other things, the "extensive" federal regulation of the same subject matter the county sought to regulate, and underscored what it thought was the lack of wisdom of making the federal lessee responsible to

35. 43 U.S.C. $\S 1712(\mathrm{c})(9)$ (1982).

36. $107 \mathrm{~S}$. Ct. at 1441.

37. See Federal Land Policy and Management Act $\S \S 701(f)$ and $(g)(6), 43$ U.S.C. $\S 1701$ (1982).

38. 601 F.2d at 1080 . 
"conflicting authority."3ө

Yet if Ventura County is to be perceived as prime authority for the proposition that federal statutes preempt the application of state land use plans on federal land, why did the majority in Granite Rock not cite it for that (nor indeed for any other) proposition? Instead, Ventura seems to have pulled a disappearing act, because Justice O'Connor's opinion plainly regards the question as an open one-"without deciding this issue." In short, Ventura's continuing viability remains at best a puzzle. Until further definitive judicial guidance is received, the states ought not to be seduced into converting the majority's assumption for the purpose of argument into an established fact. Until the question is conclusively settled they can instead continue to assert land use planning-as well as "environmental" regulatory-jurisdiction over activities occurring on federal lands.

D. May Subdivisions of State Government Apply Their Environmental Regulatory Permit Schemes on Federal Lands?

This question suggests one way to distinguish the Ventura decision from Granite Rock, for the former involved a county while the latter involved the state. Once again Justice O'Connor's majority opinion was characterized by silence, one footnote merely pointing out that no local permit requirement is involved. ${ }^{11}$

To lay fundamental preemptive emphasis on the character of the nonfederal government involved would seem to fly in the face of the long-established maxim that for nearly all federal constitutional purposes, including application of the Supremacy Clause, local governments are regarded merely as units of state government. ${ }^{42}$ Local governments derive their power from the states, and are, within state constitutional limitations, dependent upon state delegations of power. While Congress can draw distinctions

39. Id. at 1083-84, 1086.

40. $107 \mathrm{~S}$. Ct. at 1427.

41. Id. at $1427, n$.2. Interestingly, a permit from local government could at some point be required under the California Coastal Act, because once the State Coastal Commission certifies the county's land use plan under the Act, the county becomes the permitting authority. See Calif. Pub. Res. Code $\S 30600.5(b)$ (1986).

42. See J. Nowak, R. Rotunda \& J. Young, Constitutional Law 165 n.50 (3d ed. 1986); see also Mt. Healthy City School Dist. v. Doyle, 429 U.S. 274 (1977). 
between local and state government if it chooses, it does not appear to have done so very often in the context of federal lands. ${ }^{43}$

Nevertheless, there is a risk if the states and local governments push this idea too vigorously. It is probably natural to expect that the Forest Service, the BLM, and the Congress will be more willing to allow state regulation on federal lands than to tolerate regulation by every county, village, or special governmental district. At some point in this spiral downward through governmental layers, these agencies and Congress might feel compelled to intervene and aggressively invoke a national interest in how these lands are managed. And if that happens, there is a risk that, from the states' perspective, the baby (state regulation) might be thrown out with the bathwater (local regulation). Some suggestions for sidestepping that and other pitfalls are set out in the conclusion below.

\section{To What Extent Can The Federal Agencies Change The Balance Of Power Created By The Granite Rock DECISION?}

Finding no evidence that the agency had intended to preempt state law, Justice O'Connor's opinion rather curtly dismissed the miner's argument that the Forest Service's regulations ${ }^{44}$ designed to protect the use of the surface from hardrock mining operations like Granite Rock's, had themselves preempted the state permit requirement. ${ }^{46}$ The question remains whether the agency could, by amending its regulations, expressly preempt application of state permit requirements.

Although the Forest Service did not adopt its surface management regulations until $1974,{ }^{46}$ the agency had been granted regulatory authority by Congress 77 years earlier, in the 1897 Organic Act for national forest management. This act delegated legislative power to the agency to make "rules and regulations" to

43. See, e.g., 43 U.S.C. $\$ 1712(c)(9)$ (1982); cf. Lawrence County v. LeadDeadwood School Dist., 469 U.S. 256, 260-68 (1985); Columbia Basin Land Protective Ass'n v. Schlesinger, 643 F.2d 585 (9th Cir. 1981); City and County of Denver v. Bergland, 695 F.2d 465 (10th Cir. 1982).

44. 36 C.F.R. § 228 (1986).

45. $107 \mathrm{~S}$. Ct. at $1426-1427$.

46. See 39 Fed. Reg. 31317 (1974). 
"regulate [the] occupancy and use" of the forests. ${ }^{47}$ While the delegation was practically uncabined-so much so that it took two rounds of decision in the Supreme Court to uphold it against a challenge, brought by grazing interests, that it was unconstitutionally overbroad ${ }^{48}$-other parts of this same act reveal an intent that the states retain a significant measure of police power over activities on federal lands. Specifically, Congress provided that state jurisdiction should "not be affected or changed by reason of [the] existence" of the national forests. ${ }^{40}$ Thus it remains unclear whether Congress intended to grant the Forest Service the authority to preempt state law.

Analysis of the statutory authority of the other principal federal land management agency, the Bureau of Land Management in the Department of the Interior, leads to the same inconclusive conclusion. Exercising authority given it by a number of statutes, including the Federal Land Policy and Management Act and the Mining Law itself, BLM has promulgated its own generally parallel (but not identical) regulations ${ }^{50}$ to protect surface uses on BLM lands from Mining Law activities. Yet these statutes do not unequivocally delegate power to the federal agency to preempt state law; to the contrary, they fairly bristle with features designed to enhance rather than diminish the role of the states in federal land management. ${ }^{.1}$

Although one cannot say with assurance whether the federal agencies have the power, without further action by Congress, to reverse Granite Rock's holding that California's permit requirement applies, the question will arise only if a federal agency is determined to force the issue. There is ample reason to doubt whether the federal agencies have the political will even to attempt preemption. It would take eyebrow-raising action by any Administration-especially the current one, whose leader is an aggressive proponent of reinvigorated federalism ${ }^{62}$ - to attempt to

47. 16 U.S.C. $\S \S 478$ (1982). See The Mining Law, supra note 7, at 192-95.

48. United States v. Grimaud, 216 U.S. 614 (1910); 220 U.S. 506 (1911).

49. 16 U.S.C. $\S 480$ (1982); Wilson v. Cook, 327 U.S. 474, 486-87 (1945); United States v. County of Fresno, 429 U.S. 452, 455 (1977). See also 16 U.S.C. § 551(a) (1982).

50. 43 C.F.R. Part 3809 (1986).

51. See, e.g., 30 U.S.C. $\S \S 22,26,28$ (1982); 43 U.S.C. $\S \S 1712(c) ; 1714(c)(7) ;$ 1720; 1732(b)-(c); 1739(e); 1765(a) (1982).

52. President Reagan recently made preemptive strikes by federal agencies 
throw the states off the territory they have won in the hardfought battle of Granite Rock.

The federal agencies may, however, have an opportunity to preempt in a context less sweeping than changing published regulations. They could, instead, seek to preempt state regulation in their promulgation of land use plans for particular areas of federal land, or in approving plans of operations for particular mining ventures. Or the federal agencies could, by requiring a specific type of reclamation or environmental safeguard in their plans or permits, set up a conflict between their requirements and those of state law. Where compliance with otherwise lawful but conflicting dictates of state and federal governments is impossible, of course, the supremacy clause demands preemption..$^{\text {s3 }}$

Such limited preemption would not excite as much political opposition as a change in regulations of nationwide scope. Moreover, it may not be such a bad result, overall, at least if the federal agencies use a process that ensures state interests are heard and accounted for. This might mean, for example, that preemption ought to be allowed in a site-specific context only if the federal agency carefully solicits the input of state and local governments, gives full consideration to state and local interests, and makes specific findings as to why the national interest requires that a particular parcel of federal land should be used for a spe-

more difficult. His Executive Order No. 12612, 52 Fed. Reg. 41685 (October 26, 1987) admonished federal agencies to "closely examine" and "carefully assess" proposals to "limit the policymaking discretion of the States," and to adopt such proposals "only where . . . the national activity is necessitated by the presence of a problem of national scope." Id. §3(a), (b). Where, as in Granite Rock, the federal statutes do not themselves preempt state law, the Executive Order allows federal agencies to preempt by rulemaking only after notice and comment opportunity to "all affected States" (§ 4(e)), and only when the federal statute either "expressly authorizes issuance of preemptive regulations or there is some other firm and palpable evidence compelling the conclusion that the Congress intended to delegate to the department or agency the authority to issue regulations preempting State law." Id. § 4(b). Section 6 of the Order requires the federal agency considering such action to prepare and submit to the Office of Management and Budget a "Federalism Assessment" describing how the proposal complies with the Executive Order. By contrast, in the Granite Rock litigation itself, the United States filed an amicus curiae brief on the side of Granite Rock, arguing unsuccessfully that the Coastal Zone Management Act, the federal land use planning statutes, and the Mining Law all preempt the State Coastal Commission's permit requirements.

53. See $107 \mathrm{~S}$. Ct. at 1425. 
cific purpose in a specific manner that is inconsistent with state regulation. Such an approach has been suggested by a thoughtful commentator on the subject, ${ }^{54}$ and BLM has itself created a procedure akin to this by allowing state governors a special opportunity to influence BLM land use planning, and by committing the BLM to publish reasons for any decision it makes rejecting a gubernatorial recommendation. ${ }^{.5}$

While the federal agencies' power to preempt by newly modified regulations is in some doubt, no one can quibble with the idea that Congress itself could preempt. But here the political power of the states ought easily to be sufficient to withstand such a proposal. About the only way I can see Congress ever seriously considering such an approach would be as part of a general overhaul of the Mining Law itself, a subject taken up further below.

\section{How far Does Granite Rock Apply Outside The Mining Law Context?}

Focusing on the specific statutory framework before it, Justice O'Connor's majority opinion cites almost no cases, draws on no other statutes or regulatory areas for guidance by analogy, and pays little attention to the rich history of state-federal relations in land management. Yet one cannot conclude that the decision has no implications outside the framework of the Mining Law, for the majority does not really tie its analysis to the Mining Law at all, except to the limited extent it asks whether the Forest Service's surface management regulations have preempted state regulation. Instead, the majority asks whether the state regulation is land use or environmental in essential character. And that, significantly, is an issue that applies across practically the entire spectrum of possible uses of federal land.

Perhaps the most important feature of this decision, indeed, is the majority's firm rejection of dissenting Justice Powell's argument that preemption generally ought to be found more readily on federal land than in other contexts. Powell apparently views preemption issues involving federal property much as the Court has tended to view them in the foreign affairs context-as start-

54. See Freyfogle, Federal Lands and Local Communities, 27 ArIz. L. Rev. 654, 682-90 (1985).

55. See 43 C.F.R. § 1610.3-2(e) (1986). 
ing with the idea that the states must meet a heavy burden of justifying the legitimacy of their regulatory interest in light of a rather overwhelming constitutional commitment to federal supremacy. ${ }^{58}$ His citation to Hines $v$. Davidowitz ${ }^{57}$ makes clear that, for himself and Justice Stevens, (but not, apparently, for Justices Scalia and White, dissenting separately) the property clause of the constitution is akin to the war and defense powers, "imperatively ... demand[ing] broad national authority [where a]ny state power that may exist is restricted to the narrowest of limits."

The majority brushes off this suggestion without elaborate comment, rejecting any thought that "traditional pre-emption analysis is inapt in this context." not, for at least five and possibly seven Justices currently on the Court, a domestic counterpart of the foreign affairs power. By this feature alone, Granite Rock goes a substantial way toward reviving the states as genuine partners in the process of regulating activities on federal land.

Nevertheless, preemption analysis quintessentially turns on context, and especially the statutory setting. On federal lands, this will vary somewhat from resource to resource. As noted earlier, ${ }^{60}$ here the Court assumes that the Mining Law, considered by itself, allows room for the application of state regulatory permitting schemes, and therefore the only question is whether more recent and more generic federal laws like the land use planning acts have intervened to preempt otherwise applicable state laws. It remains to be seen whether the Court is equally willing to make the same assumption about other substantive federal land management statutes like the Taylor Grazing Act, the National Forest Management Act or the Mineral Leasing Act. Here too a comparison to Ventura County throws some light on Granite Rock's significance, for the Ninth Circuit opinion in the former also cited

56. 107 S. Ct. at 1437.

57. 312 U.S. 52, 66-69 (1941).

58. 312 U.S. at 68 (1941). The Ninth Circuit in its decision below had used a somewhat different but equally powerful pro-preemption analogy; namely, Congress' authority to regulate the practices of the United States Patent Office. See 768 F.2d 1077, 1082 (1982), (citing Sperry v. Florida, 373 U.S. 379 (1963)).

59. $107 \mathrm{~S}$. Ct. at 1432.

60. See supra text accompanying notes 7-9. 
Hines $v$. Davidowitz, ${ }^{61}$ and devoted far more attention to Congress's constitutional power to oust the states than to whether Congress had actually exercised that power in the Mineral Leasing Act. This was, to be sure, understandable, because the county (joined by amici states) argued "extensively that congressional enactments under the Property Clause generally possess no preemptive capability." ${ }^{62}$ The strategy behind this argument was, to say the least, questionable, for it amounted to little more than asking the lower federal courts to overrule the unanimous Supreme Court decision in Kleppe v. New Mexico, ${ }^{63}$ on which the ink was scarcely dry. The Ninth Circuit had little difficulty refusing such a misguided invitation, but the rather extreme nature of the county's argument probably influenced the court's perspective on its fall-back argument that Congress had not actually preempted local authority in the Mineral Leasing Act. By manifesting overt hostility to federal power to preempt, as well as to the activities on federal land the local government sought to regulate, it virtually invited the courts to find preemption.

With the benefit of hindsight, what seemed to happen in Ventura County was this: stung by Kleppe's unequivocal affirmation of Congress's plenary constitutional power to oust the states entirely, state and local governments perceived Ventura County as a vehicle to cut back on it and preserve some sort of constitutional protection for state power over federal lands. This was a serious mistake, for it not only led the agencies and the courts to reaffirm Kleppe on the constitutional issue, but more important, also colored their perception of preemption issues. From this perspective, what the majority did in Granite Rock was to restore a balance between state and federal power over activities on federal land that had been upset by the states' overreaction to the Kleppe case, a misunderstanding fueled by the rhetoric of the Sagebrush Rebellion than beginning to spread through the West. ${ }^{64}$

This analysis suggests, in turn, that Ventura County may no longer be a viable precedent, even in its own narrow context of

61. See 601 F.2d at 1086 (citing Hines v. Davidowitz, 312 U.S. 52 (1941)).

62. See 601 F.2d at 1083 .

63. 426 U.S. 529 (1976).

64. See, e.g., Leshy, Unraveling the Sagebrush Rebellion: Law, Politics and Federal Lands, 14 U.C. Davis L. Rev. 317 (1980). 
the Mineral Leasing Act. ${ }^{85}$ Federal regulation there seemed no more comprehensive than in Granite Rock, and the statute itself plainly preserved some room for state regulation. ${ }^{.6}$ Indeed, it is possible that the Supreme Court's decision in Commonwealth Edison v. Montana ${ }^{67}$ decided a year after Ventura County and involving the same statutory language, seriously undermined if not destroyed Ventura County's precedential value. In that case the Court upheld the state's right to enforce a rather substantial severance tax on federally owned coal. ${ }^{68}$

Ventura County might be distinguished from Granite Rock on the ground that the Mineral Leasing Act contemplates some sort of federal agency choice about the use of forest land for mineral development, while the Mining Law leaves the matter of federal land use more up to the private miner. Thus federal action with preemptive effect might be more easily found in the former context. But both statutes contain about the same degree of deference to state law, which should not be surprising because the Mineral Leasing Act simply replaced the Mining Law for certain minerals. ${ }^{68}$ Moreover, each has a "promotion of mineral development" purpose, ${ }^{70}$ and even the Mining Law, as modified by later acts, gives the federal agencies considerable say over activities conducted under it. ${ }^{71}$ Thus the differences between the two statutes would not seem to be nearly great enough to revive Ventura County.

The most significant argument for Ventura County's having some continuing viability looks to the character not of the federal scheme, but of the state or local one. There the county regulation plainly had a land use objective, ${ }^{72}$ so if that case were relitigated today, it would pose two issues left open by the Court in Granite

65. 30 U.S.C. $\S 181-287(1982)$.

66. 30 U.S.C. $\S \S 187,189$ (1982).

67. 453 U.S. 609 (1981).

68. See also Gulf Oil Corp. v. Wyoming Oil and Gas Conservation Comm'n, 693 P.2d 227, 236-38 (Wyo. 1985).

69. See The Mining Law, supra note 7, at 91-93, 102-04.

70. Compare 17 Stat. 91 (1872) (Mining Law of 1872, entitled "An Act to Promote the Development of the Mining Resources of the United States") with 41 Stat. 437 (1920) (Mineral Leasing Act of 1920, entitled "An Act to Promote the Mining of Coal, Phosphate, Oil, Oil Shale, Gas and Sodium on the Public Domain").

71. See The Mining Law, supra note 7, at 183-228.

72. See 601 F.2d at 1082. 
Rock-whether regulations that are both "land use" and local are preempted. Nonetheless, both questions could, using the analysis offered above, ${ }^{73}$ be resolved in the negative, allowing even that regulation to stand.

In non-mineral development contexts, state and local power over federal lands may likewise be enhanced by Granite Rock. Detailed consideration of federal statutes dealing with grazing, timber harvesting, recreation, wildlife and other uses of federal land is beyond my compass here, ${ }^{74}$ but the parameters of the issue can be sketched out in the following hypothetical. Protection of riparian ecosystems is commanding increasing attention from governments at all levels, as appreciation grows for their important role in flood control, water quality, fish and wildlife habitat, and recreation. If a state adopts regulations aimed at protecting riparian ecosystems, could it apply them by requiring a grazier, timber harvester, or off-road-vehicle user on federal lands to leave a riparian strip of vegetation untouched? The answer might vary with the statutory setting and the degree to which the federal agencies' own regulations have occupied the field, but absent a rather clearly preemptive statute, or a clear conflict between federal and state regulation, Granite Rock suggests it is yes.

\section{Will The Granite Rock Decision Discourage State Participation In The Federal Land Planning Processes?}

At first blush, one is tempted to answer this question in the affirmative. By upholding the state's power to require a permit under its own law, independent of the federal regulatory system, the Court appears to have invited the states to shun the opportunities nearly all federal agency land and resource planning processes afford for state and local government participation. And this invitation might seem especially appealing because these nonfederal governments have traditionally not been especially vigorous about using the opportunities to influence federal agency decisionmaking that federal law already provides. In Granite Rock itself, for example, California had unaccountably waived its right to review, against the "consistency" requirements of the fed-

73. See supra Section II.

74. See generally Freyfogle, supra note 54 , at $672-82$. 
eral Coastal Zone Management Act (CZMA), ${ }^{75}$ the plan of operations the company had submitted to the Forest Service. ${ }^{76}$

Of course, nothing in the Granite Rock decision requires the states or local governments to regulate, and some may not have an interest in the matter, or a state law scheme that permits it. Overall, in fact, the Western states' record in seeking to regulate federally sponsored activities is decidedly spotty. So far, for example, most states have not been very aggressive about taking advantage of the opportunity the Supreme Court handed them in California $v$. United States ${ }^{77}$ to control the operation of federal reclamation water projects. The political power of the reclamation beneficiaries in the affected states-beneficiaries who form one side of one of the sturdiest iron triangles in American politics-has so far been sufficient to head off most state attempts to exert an independent voice. But even here there are some signs of change, for a recent report commissioned by the Western Governors' Association recommends more vigorous state advocacy with respect to the policies of the Bureau of Reclamation. ${ }^{78}$

The states have made considerable progress in recent years adopting regulatory schemes to protect the environment. A representative of the American Mining Congress recently told a congressional committee that state environmental regulation of hard-rock mining had now become practically the norm. Only three of fourteen western states had such schemes in 1970, while ten have them today. ${ }^{78}$ Indeed, although Granite Rock involved regulation by the state Coastal Commission, California also adopted a comprehensive Surface Mining and Reclamation Act in $1975^{80}$ that, the state Attorney General has opined, ${ }^{81}$ applies to federal lands. This statute could well figure prominently in Granite Rock's operation in the aftermath of the Supreme Court's

75. See 16 U.S.C. $\S 1456(\mathrm{c})(3)(\mathrm{A})$ (1982).

76. See $107 \mathrm{~S}$. Ct. at 1423 n.1.

77. 438 U.S. 645 (1978).

78. See, e.g., B. Driver, Western Water: Tuning the System 39-46, 50-52 (REPORT TO THE WESTERN GOVERNOR's Association) (July 7, 1986).

79. See Oversight Hearings on the General Mining Law of 1872, Before the Subcomm. on Mining and Natural Resources of the House, Comm. on Interior and Insular Affairs, 100th Cong., 1st Sess. 366 (1987) (Statement of Charles C. Dietrich) (hereinafter Oversight Hearings).

80. Cal. Pub. Res. Code $\S \S 2710-2793$ (West 1984).

81. 60 Op. Cal. Att'y Gen. 162 (1977). 
decision.

Even given the increased presence of state regulatory schemes, however, the state and local governments would do well to resist the invitation to avoid participation in the federal land planning process. For one thing, Granite Rock does not eliminate the possibility that some state requirements may still, in the end, be preempted by federal law. Moreover, federal agencies retain ultimate power to authorize particular uses of federal lands, and thus remain in substantial control of what actually happens on these lands. If state and local governments want to influence these agencies directly on such questions as whether to issue mineral leases or grazing permits, conduct timber sales or set aside wildlife habitats, it will likely be more effective for them to use the federal land use planning process rather than state regulatory processes. Although their influence over the federal agencies on these questions is exercisable more through persuasion than through the force of law, it is nonetheless significant, for the political power of the states in the halls of the executive bureaucracies is usually not substantially less than their power in the halls of Congress ${ }^{82}$ Secretaries of the Interior and the heads of most important federal land management agencies, for example, usually come from the Western states and have a sensitivity that approaches an affinity for state concerns.

Another advantage of using the land use planning process is that it tends to occur earlier. The state regulatory process often comes into play only after a considerable investment of time and resources by the federal agency and any private actor involved. State and local participation in the federal land use decisionmaking process can, by contrast, head off conflicts before they ripen into entrenched, head-to-head confrontations. That process offers the means, in other words, for a comprehensive evaluation of possible federal land uses, considering all the consequences, including environmental impacts on and off federal lands that can be of particular concern to the states.

States can also use the opportunity to participate in the federal planning process as a vehicle for resolving whatever differences might exist between state and local attitudes toward partic-

82. See, e.g., Leshy, Sharing Federal Multiple Use Lands, in REThinking the Federal LANDS 265 (S. Brubaker ed. 1984). 
[Vol. 18:99

ular federal land uses. In this way, a state can convert local policies into state ones or, if it deems it appropriate, override local wishes with a different state policy. Either way, the state will avoid tempting Congress or the federal agencies to preempt purely local regulatory policies.

For their part, the federal agencies have, for many of the same reasons, ample incentive to solicit state and local participation in their planning processes, and to be solicitous of state concerns in the plans that emerge. It is especially to their advantage, both politically and from the standpoint of avoiding unnecessary paperwork, to avoid being blind-sided by state environmental regulatory requirements imposed after all the federal regulatory hurdles for a particular project have been cleared.

The Mining Law deserves special mention in this context. The states should not regard Mining Law activities conducted on federal lands as outside the federal land planning process. It is true that the self-initiation feature of that law places it somewhat apart from most environmentally significant activities that can take place on federal land, because the government's regulatory controls are exercisable in a little different way. But federal agencies possess broad authority to control these activities by regulation, or even to prohibit them altogether by means of withdrawals. Thus, as I have argued in more detail elsewhere, governmental control over Mining Law activities is an eminently sound subject for consideration in the federal land planning process. ${ }^{83}$ As an American Mining Congress spokesman recently put it, mining occupies a "unique, but not preferred, position" among natural resource uses on federal lands. ${ }^{84}$

For all these reasons, Granite Rock ought to lead to closer state-federal cooperation in the management of federal lands, with the federal land use planning process, paradoxically, as the central vehicle. Agencies in both governments might agree to a one-stop shopping permit process; for example, a state could agree not to apply its permit requirements independently of the federal process, so long as the federal government agreed to fold the state requirements into the federal plans and permits. Vari-

83. See The Mining Law, supra note 7, at 199-205.

84. See Oversight Hearings, supra note 79, at 386 (Statement of Jerry L. Haggard). 
ous arrangements might be made to eliminate duplication and streamline enforcement, akin to those already reflected in a number of memoranda of understanding the Forest Service, BLM, and various state regulatory agencies have executed over the years. ${ }^{85}$ A number of states now have "little NEPAs," statutes or administrative processes that mimic the federal National Environmental Policy Act, requiring careful advance consideration of the environmental impacts and alternatives to proposed governmental actions that could have a significant impact on environmental quality. ${ }^{86}$ In those states, joint state-federal environmental impact statements, prepared in the context of formulating land use plans or deciding upon site-specific proposals, could be a useful way to promote closer cooperation and simplify life for all concerned.

Inspection and enforcement to ensure compliance with applicable requirements is another subject that merits special attention. Users of federal land are often most aggravated not by dual state-federal permitting requirements, but rather by inconsistent or confusing exercises of inspection and enforcement authority. Moreover, it is not very productive for states to expend energy in their permitting processes if they are not willing to adopt workable methods for inspection and enforcement. Especially here, cooperative agreements between local, state and federal agencies, perhaps negotiated and even promulgated through the land use planning process, can make considerable sense for all concerned.

If the states are willing to participate in the federal land planning process more vigorously, ${ }^{87}$ and the federal agencies are willing to be more accommodating to state concerns, then Granite Rock could be a major step toward more cooperation and less confrontation between governments in federal land management. Indeed, the ultimate result of the Granite Rock decision might be for the federal agencies and the states to arrive at accommodations, reached through the federal land planning process, that approach the "consistency" requirements of the federal Coastal

85. See, e.g., Memorandum of Understanding Between the Idaho Department of Land and the Forest Service, Regions 1 and 4, Concerning Mine RecLamation Laws and REgulations (1983).

86. See, e.g., W. Rodgers, Environmental Law 809-822 (1977).

87. See Richmond, State Participation in Federal Land Planning (1983). 
Zone Management Act. ${ }^{88}$ The CZMA contains a federal floor for regulating activities in the coastal zone, encourages and facilitates state planning and regulation, and allows the states to impose more stringent requirements subject to a federal override in particular circumstances where the federal agency demonstrates a clear national need for it. Legislation may not be necessary to implement this kind of accommodation-indeed, the BLM has already begun to move toward it in its planning regulations. ${ }^{89}$

In short, both state and federal agencies have ample reason, and it would appear sufficient authority, to accommodate each other's concerns, and the planning process provides a ready framework to work through that accommodation.

\section{Granite Rock And Mining Law Reform}

Although somewhat different from the broader questions I have been discussing, I cannot resist a few words about another impact the Granite Rock decision may have on federal land management. From any perspective, the Supreme Court's decision is another nail in the coffin of the venerated or vilified-take your pick-Mining Law of 1872. Assuming that the states seize the Court's invitation to regulate, the lives of mining claimants across the West will be complicated.

As long as the Mining Law survives, however, it is conceivable that Granite Rock will promote more patenting of mining claims. That statute still offers the inducement of winning, for a token payment, fee simple title to the land embraced in a mining claim, upon compliance with the discovery and other requirements of the law. ${ }^{90}$ But few holders of unpatented claims have been willing in recent decades to try to take them to patent. ${ }^{91}$ At least one reason would appear to be a desire to avoid state taxation and regulation, for the states presumably have the same power over patented mining claims that they do over other private land within their borders. ${ }^{22}$

88. See 16 U.S.C. $\S 1456(c)(3)(A)(1982)$.

89. See supra note 55 and accompanying text; see also United States PubliC Land Law Review Commission, One Third of the Nation's Land 61-64 (1970).

90. See 30 U.S.C. $\S \S 22,29$ (1982).

91. See The Mining Law, supra note 7, at 266-69.

92. See, e.g., Oregon ex rel. State Land Bd. v. Corvallis Sand and Gravel Co., 429 U.S. 363, 377 (1977). Although the Supreme Court decided 110 years ago that 
Granite Rock largely removes the incentive to avoid patenting in order to avoid state regulation, except to the extent state power may be greater over patented as opposed to unpatented claims. Nevertheless, a significant upsurge in patent applications seems unlikely. For most mining claimants, the desire to avoid state regulation is ordinarily a much less important reason not to seek a patent than the difficulties of proving a discovery of a valuable mineral deposit and complying with the other obscure and sometimes bizarre requirements of this ancient law. ${ }^{93}$ Still, some claimants may have been held back from a patent application largely out of a fear of state regulation; indeed, the Granite Rock Company itself may fall into that category. Its federal claims were just inside the national forest boundary. Although it owns land in fee, covering the same limestone deposit, just outside the forest, it had chosen to mine only from the federal claims. ${ }^{94}$ But claimants, and the industry in general, should take little solace in the recent political flap over the Department of the Interior's decision to settle longstanding litigation over mining claims to oil shale by patenting them. ${ }^{95}$ The settlement triggered a substantial outcry, especially in Congress, over what was perceived as a woefully underpriced disposal of publicly owned resources. ${ }^{98}$ That image of a "gift" of valuable land is politically potent, and the more cases of patenting that occur, the more likely Congress will finally bestir itself to take another look at the Mining Law that makes it possible.

Granite Rock is also relevant to Mining Law reform in another way. Along with the Supreme Court's decision in United

states could tax unpatented mining claims, see cases cited supra note 27 , few states take advantage of that opportunity, so far as I am aware, because of the difficulty of identifying and valuing these claims.

93. See The Mining Law, supra note 7, at 267.

94. See Joint Appendix 31-32, California Coastal Comm'n v. Granite Rock Co., 107 S. Ct. 1419 (1987).

95. See Tosco Corp. v. Hodel, 611 F.Supp. 1130 (D. Colo. 1985); 11 Pub. Lands News 3 (August 7, 1986); 11 Pub. Lands News 2 (August 21, 1986). Although oil shale was made leasable by the Mineral Leasing Act of 1920, Mining Law claims to oil shale filed before that act were grandfathered by the legislation. 30 U.S.C. $\S 193$ (1982).

96. See 11 Pub. Lands News 3 (September 18, 1986); 11 Pub. Lands News 4 (Oct. 2, 1986); 11 Pub. Lands News 2 (Oct. 16, 1986); 12 Pub. Lands News 3 (Feb. 19, 1987); 12 Pub. Lands News 2 (March 19, 1986). 
[Vol. 18:99

States v. Locke $e^{87}$ two years earlier, it is a vivid illustration of the mining industry's loss of its exalted, preeminent place among federal land uses. The company argued strenuously that preemption was required by the "promotion of mining" policy of the federal mineral laws. But only Justice Powell in dissent (joined by Justice Stevens) paid any attention to that argument; ${ }^{98}$ the other seven justices ignored it completely. There is, a solid majority which seems to be saying, nothing special about the Mining Law or hard-rock mining on federal lands-it is just one use among many and deserves no more deference than any other use.

\section{Granite Rock In Perspective}

The Supreme Court has here seized an opportunity to restore a measure of balance to federalism in the context of federal lands. It made clear that its unanimous decision in Kleppe v. New Mex$i \mathrm{CO}^{98}$ dealt only with the constitutional power of Congress, and did not alter traditional preemption analysis. That clarification is welcome news to states given reason to worry about loss of influence by post-Kleppe decisions like Ventura. ${ }^{100}$

Taking a broader view, Granite Rock is a counterpart to the Court's earlier decision in California $v$. United States, ${ }^{101}$ where the Court rejected pro-preemption dicta in three prior opinions and revived a measure of state authority over federal reclamation projects. The two decisions are not exactly congruent; California was at once more difficult (because there the federal government was undertaking the activity directly, rather than merely authorizing private entities to act) and easier (because section 8 of the reclamation act ${ }^{102}$ is explicitly, substantially deferential to state law). But the two have the same thrust, reinvigorating the state role in federal decisionmaking in the Western states. And the legal issue in both had the same roots in the early days of westward settlement, for the original federal statute establishing a tradition of federal deference to state law on water matters, enacted in

97. 471 U.S. 84 (1985).

98. 107 S. Ct. at 1432, 1434 (Powell, J., dissenting).

99. 426 U.S. 529 (1976).

100. See supra note 10.

101. 438 U.S. 645 (1978).

102. 43 U.S.C. $\S \S 372,383(1982)$. 
$1866,{ }^{103}$ was a mining law that six years later was modified and reenacted as the Mining Law of $1872 .{ }^{104}$

As this history suggests, the tradition of state-federal partnership in the management of federal lands is strong and enduring, a not insignificant byproduct of the westward expansion of the United States and the retention of vast tracts of land in federal ownership. This partnership is most apparent, and most needed, on so-called "multiple use" lands like the national forest lands involved in Granite Rock, for on these lands Congress has itself neither prescribed a specific mix of uses nor explicitly displaced state regulatory power. ${ }^{106}$ By contrast, on numerous other categories of federal lands such as national parks, wildlife refuges, and wilderness areas, Congress has established narrower management goals. ${ }^{108}$

The preemption analysis for lands in these latter categories properly proceeds along somewhat different lines, because the more circumscribed congressional management objectives warrant more careful scrutiny of the consistency of state regulation with those objectives. Moreover, where Congress acts to narrow the management objectives for specific federal lands by including them in parks, refuges, wilderness areas or the like, the political safeguards of federalism come fully into play. Indeed, the political process of designating lands for these narrower objectives is almost always subject to veto by the state in which the land is found. It is, in short, nearly impossible to establish, say, a national park, wildlife refuge or wilderness area without the affirmative support, or at least the acquiescence, of that state, expressed through its congressional delegation. Thus the substantial displacement of state regulatory power that typically accompanies these designations occurs through a constitutionally contemplated process of consultation with, and de facto consent by, the affected state.

Inherent in the concept of "multiple use," by contrast, is a much more pervasive federal agency discretion, because Congress has authorized a much broader spectrum of activities on these lands. The very breadth of possible uses means that there is no

103. See 14 Stat. 253 (1866); codified at 30 U.S.C. $\S 51$ (1982).

104. See 17 Stat. 91 (1872); codified as amended at 30 U.S.C. $\$ \S 21-53$ (1982).

105. See Freyfogle, supra note 54 , at 672-75.

106. See, e.g., 16 U.S.C. $\$ 1$ (1982). 
single, narrow national interest in how specific tracts of these lands are managed. But multiple use is not carved in stone. Indeed, it is steadily being eroded away by a process of more specific congressional designations of federal land as wilderness, parks, refuges, areas of critical environmental concern, conservation areas, recreation areas and the like. ${ }^{107}$ The states can play a useful role in that process, by using their state regulatory processes to brake activities threatening values that residents of the Western states, and the American people, find increasingly important. As Richard Stewart has observed, "[a]llowing states and localities substantial freedom to limit natural resource development in the face of homogenizing development pressures helps to preserve . . . diversity, and with it the capacity for community identity and self-determination."108

Judicial attitudes toward preemption manifest a certain cyclical quality, roughly reflecting the sentiment prevailing elsewhere in the political system and, more broadly, in the society as a whole. Thus the Court in California v. United States ${ }^{100}$ interpreted the Reclamation Act of 1902 in a manner nearly opposite from how the Court had, in the aftermath of the federal expansion marked by the New Deal, interpreted an almost identical provision in the Federal Power Act of 1920.110 "Cooperative federalism" is today making a comeback, and there are good reasons to welcome its return.

The American West is undergoing major demographic and economic change. Now the most urban region in the country, its economic base has shifted sharply away from the traditional reliance on extractive industries like ranching, timber harvesting and mining. The political climate is changing as well. There is a growing interest in recreation, wildlife and other "softer" values found in abundance on most federal lands. In response, state environ-

107. See, e.g., Leshy, Planning as a Major Tool of Federal Land Management, (Proceedings of a Conference on The Public Lands During the Remainder of the 20th Century sponsored by the Natural Resources Law Center, U. of Colo. School of Law) (June 6, 1987); Wilkinson, The End of Multiple Use, Higr CounTRY NEws, March 30, 1987, at 15.

108. Stewart, Interstate Resource Conflicts: The Role of the Federal Courts, 6 HaRv. Envtr. L. Rev. 241, 254 (1982).

109. See 438 U.S. 645 (1978).

110. See First Iowa Hydro-Elec. Coop. v. Federal Power Comm'n, 328 U.S. 152, 175-176 (1946) (interpreting 16 U.S.C. § 821). 
mental regulatory systems have, in some places at least, been substantially improved in recent years. And, thankfully, sagebrush rebellion rhetoric has largely disappeared so that nearly everyone in the West once again seems comfortable with the presence of large federal landholdings nearby.

Thus most Western states are well-positioned to become more constructively involved in federal land management issues; specifically, to promote protection of those aspects of the environment that are so essential to the quality of life in the region. Numerous federal statutes with nationwide application, like the Clean Air and Clean Water Acts, have already given the Western states some leverage over activities conducted on federal lands. ${ }^{111}$ The Granite Rock decision gives them additional opportunities to exercise influence where gaps exist in the coverage of these national environmental laws.

It was federal multiple use policy that allowed the Granite Rock Company to begin operations to extract limestone from a national forest along the Big Sur coast. The Supreme Court has now stamped its imprimatur on the state's legitimate interest in exercising substantial influence, approaching a veto, over whether that operation shall proceed and how it shall be conducted. Although the decision does not directly resolve numerous questions about the role states can play, its implications are highly favorable to state power and, at the same time, to a progressive vision of federal land management. Cooperative federalism has indeed been given a boost on the federal lands.

111. See, e.g., 42 U.S.C. § 7418(a) (1982) (Clean Air Act); 33 U.S.C. § 1323(a) (1982) (Clean Water Act). 
HeinOnline -- 18 Envtl. L. 130 1987-1988 